\title{
PENINGKATAN KEMAMPUAN GURU SEKOLAH DASAR DALAM PENYUSUNAN INSTRUMEN RANAH SIKAP MELALUI IN HOUSE TRAINING
}

\author{
Suhandi Astuti \\ Pendidikan Guru Sekolah Dasar \\ FKIP-Universitas Kristen Satya Wacana \\ Suhandi.astuti70@gmail.com \\ Slameto \\ Magister Manajemen Pendidikan \\ FKIP-Universitas Kristen Satya Wacana \\ slameto_uksw@yahoo.com \\ Yari Dwikurnaningsih \\ Magister Manajemen Pendidikan \\ FKIP-Universitas Kristen Satya Wacana \\ yari_bkuksw@yahoo.com
}

\begin{abstract}
This study departs from the issues of teacher skills gaps in Elementary School of Laboratorium Satya Wacana in arranging the instrument of attitudes assessment. This gap problems would be solved by school action research which aims to determine the steps of in-house training that can improve teachers' skills in preparing attitudes instrument. The subjects of this study involved 15 primary school teachers of Elementary School of Laboratorium Satya Wacana. The research model that used was Stringer Model which consist of 3 aspects, namely : Look, Think, and Act. Instruments in this study were observation sheet and booklet. The data was analyzed quantitatively and qualitatively. The result showed: 1) The steps of in-house training that can improve teachers' skills are planning, implementing, and evaluating in house training. On the steps of planning, activities of the formation of a committee, determine the trainer, participants, material and schedule. During the implementation phase carried out activities ranging from pretest, delivery and discussion materials and posttest. At this stage of the evaluation carried out assessments throughout the in house training activities; 2) In-house training can enhance teachers' skills in arranging attitudes assessments during the learning process. The contribution of this research theoretically maintains the arranging steps of Likert assessment scale and practically improve teachers' skills in arranging attitude assessment in teaching and learning process.
\end{abstract}

Keywords : IH T, teachers' skills, the instrument of attitudes assessment. 


\section{PENDAHULUAN}

Lampiran Peraturan Menteri Pendidikan Nasional Nomor 16 Tahun 2007 Tanggal 4 Mei 2007 tentang Standar Kualifikasi Akademik dan Kompetensi Guru secara lengkap merumuskan kompetensi guru SD/MI. Menurut Permendiknas No.16 Tahun 2007, salah satu kompetensi pedagogik yang melekat pada profesi guru adalah menyelenggarakan penilaian dan evaluasi proses dan hasil belajar serta memanfaatkan hasil penilaian dan evaluasi untuk kepentingan pembelajaran.

Rumusan kompetensi guru di atas menjelaskan bahwa guru SD di samping menjalankan kewajiban sebagai guru juga harus melakukan penilaian pembelajaran. Penilaian dilakukan dengan tahapan awal memahami hakikat penilaian, memahami cakupan ranah atau aspek yang dinilai, merancang prosedur penilaian, menyusun instrumen, melaksanakan penilaian, mengadministrasikan hasil, mengolah hasil, melaporkan hasil dan menggunakan hasil penilaian untuk melakukan pembinaan siswa dan memperbaiki pembelajaran.

Popham seperti dikutip oleh Naniek Sulistyawardani, dkk (2012: 94) menyatakan bahwa keberhasilan seseorang dipengaruhi oleh kondisi afeksinya. Seseorang dengan kemampuan afektif yang buruk tentu akan kesulitan mencapai keberhasilan belajar yang optimal. Oleh karena itu, pendidikan harus memberikan perhatian yang serius menyangkut pengembangan penilaian ranah afektif.

Camellia dan Umi Chotimah (2012) meneliti tentang kebiasaan guru dalam melakukan penilaian di Ogan Ilir, menemukan bahwa : 1) guru sering menilai siswa hanya dari sisi kemampuan kognitif saja, 2) guru sebenarnya mengetahui akan pentingnya penilaian ranah sikap siswa, 3) guru belum bisa secara maksimal membuat dan melaksanakan penilaian ranah sikap, 4) guru 38 ingin membuat instrumen penilaian ranah sikap.

Permasalahannya adalah apakah para guru SD telah merancang dan melaksanakan penilaian ranah sikap tersebut dengan baik? Pertanyaan tersebut dapat dijawab dengan melihat fenomena yang terjadi melalui kajian penelitian yang sudah ada dan studi awal penelitian.

Hasil studi pendahuluan yang dilakukan peneliti dengan melibatkan 13 guru SD Laboratorium Kristen Satya Wacana menunjukkan temuan berikut : 1) Hanya $31 \%$ guru yang telah melakukan penilaian mencakup tiga ranah (kognitif, afektif, dan psikomotor); 2) Hanya $31 \%$ guru yang melakukan penilaian non tes jenis skala sikap untuk mengukur sikap siswa; 3) Hanya 23\% guru yang memiliki pemahaman yang cukup untuk mengembangkan penilaian sikap; dan 4) Hanya $15 \%$ guru yang memiliki pemahaman yang cukup untuk mengembangkan instrumen penilaian skala sikap model Likert.

Berdasarkan riset di lapangan seperti yang telah diuraikan di atas, nampak bahwa terdapat kesenjangan yang sangat besar antara praktik penilaian yang ideal dengan kenyataan yang terjadi, secara berturut-turut 69\%, 69\%, $77 \%$ dan $85 \%$. Kesenjangan yang besar ini merupakan kebutuhan yang harus dipenuhi melalui tindakan pelatihan. Model tindakan pelatihan untuk memperbaiki fenomena rendahnya kemampuan guru dalam menyusun instrumen penilaian ranah sikap adalah model In House Training (IHT).

Terdapat sejumlah penelitian tentang IHT yang efektif meningkatkan kemampuan guru. Pertama, penelitian Fidyawati (2013) yang berjudul "Efektifitas In House Training dalam Peningkatan Kompetensi Guru di SMA Laboratorium Percontohan UPI Bandung", menemukan bahwa In House Training (IHT) mempunyai peranan yang sangat penting bagi guru PKn dalam meningkatkan kompetensi melalui pelatihan-pelatihan. Kedua, penelitian 
Heldy Eriston (2011) berjudul "Meningkatkan Kemampuan Guru dalam Membuat Powerpoint melalui In House Training di SMK Teknik Industri Purwakarta", yang amenyimpulkan bahwa In House Training bermanfaat untuk meningkatkan kemampuan guru membuat powerpoint untuk media pembelajaran. Tindakan yang telah mencapai hasil $86 \%$ melampaui indikator yang telah ditetapkan yaitu $75 \%$ menunjukkan bahwa IHT dapat secara signifikan meningkatkan kemampuan guru membuat powerpoint untuk media pembelajaran. Ketiga, penelitian Shakoor, A., Ghumman, M.S., Mahmood, T. (2013) berjudul "Effect of In Service Training on the Working Capacity and Performance of Science Teachers at Secondary Level'. Hasil penelitian menunjukkan In Service Training memiliki dampak capaian yang tinggi dan positif pada kompetensi profesional, serta membuat pelaksanaan kurikulum lebih efektif. Keempat, penelitian Naill Hegarty (2014) berjudul "Can in-house training programs replace the graduate degree? An exploration of differences and learning objectives in terms of career advancement", hasil temuan menunjukkan program pelatihan sangat penting, karena melalui perbaikan program pelatihan tujuan organisasi maupun individu dapat tercapai.

Berkaitan dengan kompetensi guru Mulyasa (2003: 20) mengemukakan bahwa kompetensi guru : “...is a knowledge, skills, and abilities or capabilities that a person achieves, which become part of his or her being to the extent he or she can satisfactorily perform particular cognitive, affective, and psychomotor behaviors". Dalam hal ini, kompetensi guru diartikan sebagai pengetahuan, ketrampilan, dan kemampuan yang dikuasai oleh guru yang telah menjadi bagian dari dirinya, sehingga ia dapat melakukan perilaku-perilaku kognitif, afektif, dan psikomotorik dengan sebaik-baiknya. Sejalan dengan itu Mulyasa (2003: 21) mengartikan kompetensi guru sebagai penguasaan terhadap suatu tugas, keterampilan, sikap, dan apresiasi yang diperlukan untuk menunjang keberhasilan. Muhaimin (2004: 59) menjelaskan kompetensi adalah seperangkat tindakan intelegen penuh tanggung jawab yang harus dimiliki seseorang sebagai syarat untuk dianggap mampu melaksanakan tugas-tugas dalam bidang pekerjaan tertentu. Sifat intelegen harus ditunjukkan sebagai kemahiran, ketetapan, dan keberhasilan bertindak. Sifat tanggung jawab harus ditunjukkan sebagai kebenaran tindakan baik dipandang dari sudut ilmu pengetahuan, teknologi maupun etika.

Depdiknas (2005 : 34) merumuskan definisi kompetensi guru sebagai pengetahuan, ketrampilan, dan nilai-nilai dasar yang dimiliki oleh seorang guru, yang direfleksikan dalam kebiasaan berfikir dan bertindak. Menurut Syah (2000: 35), "kompetensi" adalah kemampuan, kecakapan, keadaan berwenang, atau memenuhi syarat menurut ketentuan hukum. Selanjutnya masih menurut Syah, dikemukakan bahwa kompetensi guru adalah kemampuan seorang guru dalam melaksanakan kewajiban-kewajiban secara bertanggung jawab dan layak.

Tentang In House Training menurut Sujoko (2012: 40) In House Training merupakan program pelatihan yang diselenggarakan di tempat sendiri, sebagai upaya untuk meningkatkan kompetensi guru dalam menjalankan pekerjaan dengan mengoptimalkan potensi-potensi yang ada. Sedangkan menurut Danim (2011: 94) In House Training (IHT) merupakan program pelatihan yang dilaksanakan secara internal oleh kelompok kerja guru, sekolah atau tempat lain yang ditetapkan sebagai penyelenggaraan pelatihan yang dilakukan berdasarkan pada pemikiran bahwa sebagian kemampuan dalam meningkatkan kompetensi dan karier guru tidak harus dilakukan secara eksternal, namun dapat dilakukan secara internal, Danim juga 
memberi batasan peserta dalam IHT minimal 4 orang dan maksimal 15 orang. Berdasarkan pengertian dari Sujoko dan Danim, nampak bahwa esensi dari IHT adalah kegiatan untuk meningkatkan kompetensi guru dengan menggunakan segala sarana dan prasarana yang ada di sekolah.

Tujuan IHT menurut Lulu Kamaludin (2011: 2) dan Meldona (2009: 234) adalah: a) meningkatkan kualitas Sumber Daya Manusia (SDM); b) memperbaiki kinerja, c) menciptakan interaksi antar peserta; d) mempererat rasa kekeluargaan dan kebersamaan; serta e) meningkatkan motivasi dan budaya belajar yang berkesinambungan. Dari sisi keuntungan Lulu Kamaludin (2011: 2) menyebutkan: a) Hasil lebih maksimal, b) Materi lebih spesifik, c) Biaya lebih murah.

Berkaitan dengan langkah-langkah $I H T$, Marwansyah (2012: 170), menjelaskan bahwa IHT dilakukan melalui tiga fase, yaitu: 1) fase Perencanaan, hal-hal yang perlu dilakukan pada fase ini adalah: menentukan sasaran pelatihan; menentukan tujuan pelatihan; menentukan pokok bahasan/ materi pelatihan; menentukan pendekatan dan metodologi pelatihan; menentukan peserta pelatihan dan fasilitator (trainer); menentukan waktu dan tempat pelatihan; menentukan semua bahan yang diperlukan dalam pelatihan; menentukan model evaluasi pelatihan; menentukan sumber dana pembiayaan yang dibutuhkan, 2) fase proses penyelenggaraan, proses penyelenggaraan pelatihan pada dasarnya merupakan implementasi dari perencanaan. Fase ini dibagi menjadi dua tahapan yaitu tahap persiapan dan tahap pelaksanaan pelatihan. Pada tahap persiapan, proses pelatihan meliputi: mempersiapkan kelengkapan bahan pelatihan (undangan pemberitahuan, materi, jadwal, media, daftar hadir, instrumen evaluasi) dan kesiapan sarana prasarana (tempat, fasilitas, konsumsi, peserta maupun trainer) (Nawawi, 2008 : 228), 3) fase evaluasi pelatihan, fase evaluasi adalah fase penilaian terhadap kegiatan pelatihan yang telah dilaksanakan.

Berdasarkan uraian di atas maka rumusan masalah dalam penelitian ini adalah 1) Bagaimanakah langkah-langkah pelatihan model In House Training yang terbukti meningkatkan kemampuan guru SD dalam menyusun instrumen penilaian ranah sikap dan 2) Apakah pelatihan model In House Training dapat meningkatkan kemampuan guru SD dalam menyusun instrumen penilaian ranah sikap.

Kontribusi temuan penelitian tindakan sekolah melalui In House Training ini adalah memberikan pembuktian bahwa peningkatan kemampuan guru dalam menyusun instrumen penilaian ranah sikap dapat ditingkatkan melalui kegiatan In House Training.

\section{METODE PENELITIAN}

Penelitian tindakan sekolah ini dikategorikan sebagai penelitian tindakan kolaboratif atau collaborative action research. Desain penelitian ini menggunakan model Stringer yang ditandai dengan tiga kata : 1) Look (melihat) yaitu kegiatan untuk memahami permasalahan melalui pengumpulan data dan mendeskripsikan situasi; 2) Think (berfikir) yaitu kegiatan menganalisis apa yang terjadi dan menginterpretasikan bagaimana dan mengapa hal itu terjadi; 3) Act (berbuat) yaitu melakukan tindakan (Yaumi \& Damopolli, 2014: 10).

Penelitian ini terdiri dari 2 siklus yang masing-masing siklus terdiri dari 2 pertemuan. Penelitian dilaksanakan di SD Laboratorium Kristen Satya Wacana Salatiga pada bulan Agustus sampai bulan Oktober 2016. Subyek penelitian tindakan sekolah ini yaitu guru-guru SD Laboratorium Kristen Satya Wacana dengan jumlah guru sebanyak 15 orang. Sumber data dalam penelitian ini adalah guru, kepala sekolah, dan catatan lapangan oleh peneliti. 
Teknik dan instrumen pengumpulan data menggunakan teknik tes dengan isntrumen berupa soal pretest dan posttest dan teknik non tes dengan instrumen lembar observasi dan dokumentasi.

Indikator keberhasilan penerapan pelatihan model IHT adalah apabila skor aktivitas trainer dan guru sebagai peserta pelatihan mencapai kategori baik, dan skor kemampuan guru minimal 60, dengan ketuntasan klasikal peserta pelatihan mencapai $80 \%$. Teknik analisis data menggunakan teknik deskriptif kategoris dan komparatif. Teknik komparatif digunakan untuk mendeskripsikan capaian kemampuan peserta IHT antar siklus. Sedangkan teknik deskriptif kategoris digunakan untuk mendeskripsikan kategori hasil observasi aktivitas trainer dan peserta IHT serta kemampuan guru, dengan kategori berikut:

Tabel 1 Tabel Katagorisasi

\begin{tabular}{|c|c|}
\hline Capaian hasil (\%) & Kategori \\
\hline $81-100$ & Baik sekali \\
\hline $61-80$ & Baik \\
\hline $41-60$ & Cukup \\
\hline $21-40$ & Kurang \\
\hline $1-20$ & Kurang sekali \\
\hline
\end{tabular}

\section{HASIL DAN PEMBAHASAN}

\section{Hasil Penelitian}

Kemampuan awal guru SD Laboratorium Kristen Satya Wacana dalam menyusun instrumen penilaian ranah sikap masih rendah. Hal ini nampak pada data awal yang dikumpulkan melalui observasi dan angket yang dilakukan terhadap guru. Berdasarkan data yang dikumpulkan 31\% guru melakukan penilaian mencakup tiga ranah kognitif, afektif, dan psikomotor, $31 \%$ guru melakukan penilaian non tes jenis skala sikap untuk mengukur sikap siswa, 23\% guru yang memiliki pemahaman cukup untuk mengembangkan penilaian sikap dan $15 \%$ guru memiliki pemahaman cukup untuk mengembangkan instrumen penilaian skala sikap model Likert. Dalam upaya meningkatkan kemampuan melakukan penilaian ranah sikap terhadap guru SD Laboratorium Kristen Satya Wacana, maka perlu dilakukan tindakan $I H T$.

Penelitian ini terdiri dari 2 siklus, masing-masing siklus terdiri dari 2 pertemuan. Pada siklus 1 pertemuan pertama materi pelatihan yang diberikan mencakup: a) analisis kompetensi dasar, b) pengantar umum penilaian, c) hakikat penilaian sikap. Materi siklus 1 pertemuan kedua mencakup materi: d) teori penyusunan instrumen penilaian sikap model skala Likert, dan e) menentukan obyek sikap skala Likert.

Pada siklus 2 pertemuan pertama materi yang diberikan mencakup: a) uji coba instrumen skala Likert, b) menentukan skor hasil uji coba instrumen. Materi Siklus 2 pertemuan kedua mencakup materi menghitung tingkat reliabilitas dan validitas instrumen skala sikap. Ketuntasan hasil kegiatan IHT siklus I dapat dilihat pada tabel 2 dibawah ini.

Pencapaian kemampuan hasil belajar pada Siklus I, meskipun telah mencapai KKM sebesar 76, 92\% peserta telah memperoleh skor $\geq 60$, namun capaian Siklus I ini belum berhasil. Dilihat dari rerata skor posttest Siklus I juga belum tinggi, baru mencapai 64, 6 . 
Tabel 2 Rekapitulasi Ketuntasan Hasil Kegiatan IHT Siklus I

\begin{tabular}{|l|l|l|l|}
\hline No & \multicolumn{1}{|c|}{ Kriteria } & \multicolumn{1}{|c|}{ Angka } & \multicolumn{1}{c|}{$\%$} \\
\hline 1 & KKM & $\geq 60$ & \\
\hline 2 & Tuntas & 10 orang & $76,92 \%$ \\
\hline 3 & Tidak tuntas & 3 orang & $23,07 \%$ \\
\hline 4 & Rata-rata & 64,6 & \\
\hline 5 & Nilai tertinggi & 75 & \\
\hline 6 & Nilai terendah & 55 & \\
\hline
\end{tabular}

Sumber: Data penelitian

Hal ini disebabkan trainer cenderung memaparkan atau mempresentasikan materi ketimbang melakukan kegiatan mendorong peserta untuk membaca materi dalam hand out. Ketuntasan hasil kegiatan IHT siklus II dapat dilihat pada tabel 3 dibawah ini.

Tabel 3 Rekapitulasi Ketuntasan Hasil Kegiatan

$$
\text { IHT Siklus II }
$$

\begin{tabular}{|c|l|c|c|}
\hline No & \multicolumn{1}{|c|}{ Kriteria } & Angka & $\%$ \\
\hline 1 & KKM & $\geq 60$ & \\
\hline 2 & Tuntas & 12 & $80 \%$ \\
\hline 3 & Tidak tuntas & 3 & $20 \%$ \\
\hline 4 & Rata-rata & 60,33 & \\
\hline 5 & Nilai tertinggi & 70 & \\
\hline 6 & Nilai terendah & 45 & \\
\hline
\end{tabular}

Sumber: Data penelitian

Dari data dalam tabel 3 nampak bahwa pencapaian kemampuan hasil belajar pada Siklus II telah berhasil, karena terdapat $80 \%$ peserta $I H T$ memperoleh skor $\geq 60$. Meskipun rerata capaian kemampuan belajar peserta masih rendah, yaitu 60,33. Data rerata ini lebih rendah dari rerata kemampuan hasil belajar Siklus I $(64,6)$.

Secara visual komparasi pretest dan posttest siklus I dan II dapat dicermati pada grafik berikut.

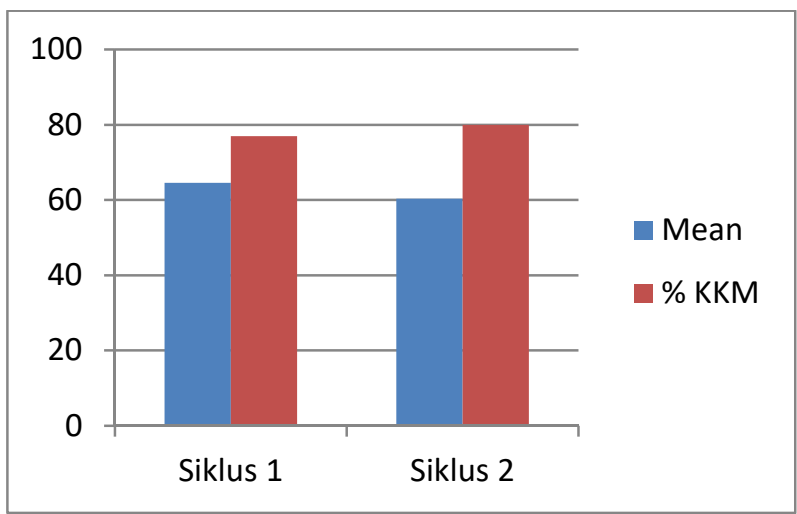

Gambar 1 Grafik Komparasi Rerata dan Persentase Capaian Kemampuan Hasil IHT Siklus I dan II

Berdasarkan data komparasi seperti di atas, dapat dikemukakan beberapa temuan berikut: a) IHT penulisan instrumen penilaian kawasan afektif pada Siklus I belum berhasil. Ketidakberhasilan ini didasarkan pada temuan hasil belajar peserta IHT yang baru mencapai 76, 92\%, padahal berdasarkan kriteria IHT berhasil jika minimal $80 \%$ peserta mencapai skor $\geq 60$; b) IHT penulisan instrumen penilaian kawasan afektif pada Siklus II berhasil. Keberhasilan ini didasarkan pada temuan hasil belajar peserta IHT yang telah mencapai minimal $80 \%$ peserta mendapat skor $\geq 60$; meskipun ada penurunan rerata skor dari 64,6 pada Siklus I menjadi 60,33 pada Siklus II.

\section{PEMBAHASAN}

Penelitian Tindakan Sekolah menggunakan model IHT ini bermula dari permasalahan praktik penilaian di SD Laboratorium Kristen Satya Wacana yang belum menggunakan instrumen penilaian ranah sikap. Salah satu penyebab adalah kemampuan guru dalam menyusun instrumen penilaian ranah sikap masih belum memadai. Kepala sekolah memutuskan bahwa tindakan pemecahan masalah yang dilakukan adalah dengan melaksanakan penelitian tindakan sekolah (PTS).

Ada dua pertanyaan penelitian yang dijadikan pedoman dalam melaksanakan PTS 
ini, yaitu: Bagaimanakah langkah-langkah pelatihan model In House Training yang dapat meningkatkan kemampuan guru SD Laboratorium Kristen Satya Wacana dalam menyusun instrumen ranah sikap?; dan Apakah pelatihan model In House Training dapat meningkatkan kemampuan guru SD Laboratorium Kristen Satya Wacana dalam menyusun instrumen penilaian ranah sikap? Berdasarkan dua pertanyaan penelitian di atas, berikut ini dipaparkan temuan dan pembahasan dua permasalahan tersebut.

IHT dilakukan melalui tiga fase, yaitu fase perencanaan, fase proses penyelenggaraan dan fase evaluasi. Melalui diklat model $I H T$, guru mengasah kemampuan secara aktif dengan mengeksplorasi materi pelatihan secara konsisten, persisten dan mengarah pada tujuan yang ingin dicapai dan kemudian mengelaborasi dengan mengerjakan tugastugas mandiri maupun kelompok. Langkahlangkah pelatihan model IHT yang menyebabkan keberhasilan pelatihan ini terlihat dari aktivitas setiap langkah IHT, terutama langkah-langkah pada fase proses penyelenggaraan IHT.

Hasil observasi aktivitas trainer maupun peserta IHT menunjukkan perolehan skor $71 \%$ sampai $95 \%$ artinya berada pada kategori baik dan sangat baik. Sedangkan aktivitas peserta memperoleh skor 93,2\% sampai $98 \%$ artinya berada pada ketegori sangat baik. Dilihat dari hasil postes, pada Siklus I mencapai rata-rata 64,6 dan persentase ketuntasan 76,92\%. Pada Siklus II mencapai rata-rata 60,33 dan ketuntasannya mencapai $80 \%$. Jika temuan ini dikaitkan dengan kriteria keberhasilan PTS dengan indikator keberhasilan pelatihan IHT dikatakan berhasil apabila skor aktivitas trainer dan guru sebagai peserta pelatihan mencapai kategori baik dan skor kompetensi guru minimal 60 dengan ketuntasan klasikal peserta pelatihan mencapai $80 \%$, maka dapat dikatakan bahwa PTS siklus I dan II semuanya berhasil.
Keberhasilan aktivitas PTS pada siklus I ditunjukkan oleh langkah-langkah berikut: a) trainer menyampaikan materi teori penyusunan instrumen penilaian sikap model skala Likert; b) trainer membagi menjadi 4 kelompok dan selanjutnya peserta secara kelompok melakukan analisis kasus contoh instrumen penilaian sikap yang benar dan kurang benar kemudian dianalisis sesuai dengan langkah-langkah skala sikap model Likert; c) selanjutnya peserta melakukan diskusi kelompok untuk menyusun item pernyataan skala sikap sesuai obyek sikap yang telah ditentukan; d) trainer berkeliling ke setiap kelompok untuk memantau, membimbing serta memberikan kesempatan kepada kelompok untuk menanyakan materi yang belum dikuasai.

Berdasarkan hasil refleksi bahwa aktivitas IHT pada siklus I berhasil, maka pada siklus II langkah-langkah IHT secara umum sama, yaitu: a) trainer mendorong peserta untuk membaca materi dalam hand out tentang berbagai teori mengenai instrumen penilaian skala sikap; b) trainer membagi peserta menjadi 4 kelompok dan selanjutnya peserta melakukan diskusi kelompok; c) trainer berkeliling ke setiap kelompok untuk memantau dan membimbing setiap kelompok dan d) trainer memberikan kesempatan kepada kelompok untuk bertanya tentang materi yang belum difahami/ dimengerti.

Hasil evaluasi pelaksanaan IHT berkaitan dengan pertanyaan apakah materi bermanfaat bagi peserta, $97 \%$ peserta menyatakan bermanfaat. Hal ini didukung juga oleh respon terhadap pertanyaan apakah interaksi antara trainer dengan peserta dan penggunaan alat bantu pelatihan efektif. Responnya berturut-turut mencapai $96 \%$ dan 96\% menyatakan efektif. Keefektifan langkahlangkah IHT ini sejalan dengan pandangan Marwansyah (2012: 170) yang menjelaskan bahwa IHT dilakukan melalui tiga fase, yaitu fase perencanaan, fase proses penyelenggaraan 
dan fase evaluasi. Temuan keberhasilan langkah-langkah PTS ini mendukung juga teori In House Training, yang merupakan program pelatihan yang diselenggarakan di tempat sendiri dan diupayakan untuk meningkatkan kompetensi guru dalam menjalankan pekerjaannya dengan penggunaan alat peraga, dan dilaksanakan di sekolah tempat guru tersebut bekerja (Sujoko, 2012: 40; dan Danim, 2011:94).

Temuan dalam penelitian ini menunjukkan bahwa IHT yang dilaksanakan di SD Laboratorium Kristen Satya Wacana berhasil meningkatkan kemampuan guru dalam menyusun instrumen penilaian ranah sikap. Pada saat kondisi awal hanya $15 \%$ guru atau hanya 2 guru yang memiliki pemahaman yang cukup untuk mengembangkan instrumen penilaian skala sikap model Likert. Dari data yang sudah dipaparkan di atas tampak pada siklus 1 tingkat ketuntasan mencapai $76.9 \%$ atau 10 guru dari 13 guru SD Laboratorium Kristen Satya Wacana mampu memenuhi Kriteria Ketuntasan Minimal yaitu mencapai skor 60. Meskipun capaian ini belum dikatakan berhasil. Baru pada siklus 2 tingkat ketuntasan mencapai $80 \%$ atau 12 guru dari 15 guru SD Laboratorium Kristen Satya Wacana mampu memenuhi Kriteria Ketuntasan Minimal yaitu mencapai skor 60. Dengan demikian capaian ketuntasan peserta $I H T$ pada siklus ke II ini dikatakan berhasil.

Temuan keberhasilan langkah-langkah PTS ini sesuai dengan Tujuan IHT menurut Lulu Kamaludin (2011: 2) dan Meldona (2009: 234) yaitu: a) meningkatkan kualitas Sumber Daya Manusia (SDM); b) memperbaiki kinerja, c) menciptakan interaksi antara peserta; d) mempererat rasa kekeluargaan dan kebersamaan; serta e) meningkatkan motivasi dan budaya belajar yang berkesinambungan. Dari sisi keuntungan Lulu Kamaludin (2011: 2) menyebutkan: a) Hasilnya lebih maksimal, b) Materinya lebih spesifik, c) Biaya lebih murah.
Temuan keberhasilan IHT untuk meningkatkan kompetensi guru ini sesuai dengan hasil penelitian yang dikemukakan oleh Fidyawati (2013) dalam penelitiannya tentang Efektifitas In House Training dalam Peningkatan Kompetensi Guru di SMA Laboratorium Percontohan UPI Bandung, menemukan bahwa In House Training (IHT) mempunyai peranan yang sangat penting bagi guru PKn dalam meningkatkan kompetensi melalui pelatihan-pelatihan.

Temuan penelitian ini mendukung penelitian tindakan yang dilakukan penulis khususnya tentang Efektifitas In House Training dalam meningkatkan kompetensi guru. Seperti penelitian Heldy Eriston (2011) yang melakukan penelitian tindakan sekolah tentang Meningkatkan Kemampuan Guru dalam Membuat Powerpoint melalui In House Training di SMK Teknik Industri Purwakarta. Hasilnya menyimpulkan In House Training bermanfaat untuk meningkatkan kemampuan guru membuat powerpoint untuk media pembelajaran. Tindakan yang telah mencapai hasil $86 \%$ melampaui indikator yang telah ditetapkan yaitu $75 \%$ menunjukkan bahwa IHT dapat secara signifikan meningkatkan kemampuan guru membuat powerpoint untuk media pembelajaran. Temuan lain dikemukakan oleh Shakoor, A., Ghumman, M.S., Mahmood, T. (2013) yang meneliti tentang pengaruh In Service Training terhadap kapasitas kerja dan kinerja guru sain di tingkat menengah. Hasil penelitian menunjukkan In Service Training memiliki dampak capaian yang tinggi dan positif pada kompetensi profesional, serta membuat pelaksanaan kurikulum lebih efektif. Demikian juga dengan penelitian Naill Hegarty (2014) menulis tentang keefektifan program pelatihan dalam hal tujuan pembelajaran, sebagai sebuah media untuk meningkatkan karir individu, dan sebagai suatu bentuk dari pendidikan yang diakui. Hasil temuan menunjukkan program pelatihan sangat penting, karena melalui 
perbaikan program pelatihan tujuan organisasi maupun individu dapat tercapai.

Kontribusi temuan penelitian tindakan sekolah melalui In House Training ini adalah memberikan pembuktian bahwa peningkatan kemampuan guru dalam menyusun instrumen penilaian ranah sikap dapat ditingkatkan melalui kegiatan In House Training. Kemampuan yang meningkat berkaitan dengan pemahaman konsep mengenai kemampuan memahami pengantar umum penilaian, memahami hakekat penilaian sikap, mendiskripsikan teori penyusunan instrumen penilaian sikap model skala Likert. Kontribusi penelitian ini secara teoritis memantapkan/ menguatkan teori Azwar tentang langkahlangkah penyusunan skala sikap model skala Likert.

Kontribusi penelitian ini secara praktik dapat meningkatkan kemampuan menganalisis kompetensi dasar dalam silabus kurikulum SD 2013, menyusun instrumen penilaian sikap model skala Likert, melakukan uji coba instrumen, menghitung tingkat reliabilitas dan validitas instrumen skala sikap. Dan selanjutnya menyusun instrumen penilaian ranah sikap dalam pembelajaran pada topiktopik tertentu.

Kontribusi secara konsep dan praktek yang telah diuraikan itulah yang membedakan dengan hasil penelitian relevan hasil terdahulu. Temuan Fidyawati (2013) sebatas peran In House Training dalam meningkatkan kompetensi guru PKn. Temuan Heldy Eriston (2011) sebatas manfaat In House Training dalam meningkatkan kemampuan guru membuat powerpoint untuk media pembelajaran. Temuan Shakoor, A., Ghumman, M.S., Mahmood, T. (2013) sebatas dampak In Service Training pada kompetensi guru. Temuan Nail Hegarty (2014) sebatas pentingnya program pelatihan untuk tercapainya tujuan organisasi maupun individu.

\section{SIMPULAN DAN SARAN}

\section{Simpulan}

Berdasarkan temuan dan hasil pembahasan di atas, berikut disampaikan dua simpulan dari Penelitian Tindakan Sekolah ini. Pertama, langkah-langkah pelatihan model In House Training yang dapat meningkatkan kemampuan guru SD Laboratorium Kristen Satya Wacana dalam menyusun instrumen ranah sikap adalah perencanaan, pelaksanaan dan evaluasi IHT. Pada langkah perencanaan dilakukan kegiatan: a) membentuk panitia $I H T$; b) menghubungi ahli yang berkompeten dalam bidang penyusunan instrumen penilaian ranah sikap untuk menjadi trainer; c) mengundang guru untuk menjadi peserta; d) menyiapkan materi; dan e) membuat jadwal pelaksaaan.

Pada langkah pelaksanaan dilakukan kegiatan: a) memberikan pretest sebelum dilakukan sesi pelatihan, b) melakukan sesi pelatihan dengan tahapan: (1) trainer mendorong peserta untuk aktif membaca materi pelatihan dalam bentuk hand out; (2) peserta pelatihan dengan bimbingan trainer membagi menjadi 4 kelompok dan selanjutnya peserta melakukan diskusi kelompok; (3) trainer berkeliling ke setiap kelompok untuk memantau dan membimbing diskusi kelompok; dan (4) trainer memberikan kesempatan kepada kelompok untuk bertanya tentang materi yang belum dimengerti, c) melakukan observasi untuk memantau aktivitas trainer dan peserta pelatihan.

Pada langkah evaluasi dilakukan kegiatan: a) posttest untuk mengetahui sejauhmana tingkat kemampuan guru dalam menyusun instrumen penilaian ranah sikap dapat tercapai; dan b) evaluasi program $I H T$ secara keseluruhan mencakup pengorganisasian, pelaksanaan, kemanfaatan materi pelatihan, kompetensi trainer, kepuasan peserta pelatihan.

Kedua, pelatihan model In House Training dapat meningkatkan kemampuan guru SD Laboratorium Kristen Satya Wacana 
dalam menyusun instrumen penilaian ranah sikap; Simpulan ini didasarkan data peningkatan persentase peserta pelatihan yang mencapai KKM (kriteria keberhasilan $\geq 60$ ) dari $76,92 \%$ pada siklus I menjadi $80 \%$ pada siklus II. Simpulan ini juga didukung capaian aktivitas trainer maupun peserta pelatihan pada kategori baik dan sangat baik untuk semua siklus.

\section{Saran}

Berdasarkan simpulan Penelitian Tindakan Sekolah tentang pelatihan model In House Training dalam rangka meningkatkan kemampuan guru SD Laboratorium Kristen Satya Wacana dalam menyusun instrumen ranah sikap, dapat disampaikan saran-saran berikut:

a. Bagi guru, disarankan menerapkan kemampuannya menyusun instrumen penilaian ranah sikap dalam pembelajaran, khususnya yang berkaitan dengan domain kompetensi inti (KI) sikap.

b. Bagi kepala sekolah disarankan agar melanjutkan penelitian tindakan sekolah menggunakan model IHT untuk meningkatkan kemampuan gurunya. Khususnya kemampuan dalam menyusun instrumen penilaian ranah sikap.

c. Bagi pengawas, dapat disarankan mendorong para kepala sekolah dan guru agar terus-menerus meningkatkan kemampuannya melalui kegiatan IHT di sekolah. Khususnya kemampuan dalam menyusun penilaian ranah sikap.

d. Bagi peneliti lain yang akan melakukan penelitian lanjutan, disarankan agar melakukan penelitian ulang tentang penyusunan instrumen ranah sikap model Likert minimal tiga siklus, dengan harapan hasilnya akan lebih meningkat.

\section{DAFTAR PUSTAKA}

Alfaris, Sujoko. 2012. Peningkatan Kemampuan Guru Mata Pelajaran
Melalui In House Training. Jurnal Pendidikan Penabur. 11 (18): 27-39

Camelia dan Umi Chotimah. 2012. Kemampuan Guru Membuat Instrumen Penilaian Domain Afektif Mata Palajaran PKn di SMP Negeri SeKabupaten Ogan Ilir. Jurnal Forum Sosial, Kajian Pendidikan Ilmu Pengetahuan Sosial dan Ilmu Sosial. V (02):114 - 122.

Danim Sudarwan dan Khairil. 2011. Profesi Kependidikan. Bandung. Alfabeta

Eriston Heldy. 2011. Meningkatkan Kemampuan Guru dalam Membuat Power point melalui in House Training di SMK Teknik Industri Purwakarta.

Fidyawati. 2013. Efektifitas In House Training Dalam Peningkatan Kompetensi Guru, di SMA Laboratorium Percontohan UPI di Bandung. Bandung: Universitas Pendidikan Indonesia.

Hegarty, N. 2014. Can in-house training programs replace the graduate degree? An exploration of differences and learning objectives in terms of career advancement.BRC Journal of Advances in Education, 2 (1): 13-34.

Lulu Kemaludin. 2011. Pengertian In House Training, tujuan dan Manfaatnya. http://tikettraining.com/pengertian-inhouse-training-tujuan-dan-manfaatnya. Diunduh tanggal 9 Oktober 2015.

Mawansyah. 2010. Manajemen Sumber Daya Manusia. Bandung: Alfabeta

Meldona. 2009. Manajemen Sumber Daya Manusia. Malang : UIN Malang Press.

Muhaimin 2004. Paradigma Pendidikan Islam. Bandung: PT Remaja Rosdakarya. 
Muhammad Yaumi \& Muljono Damopolli. 2014. Action Research: Teori, Model, dan Aplikasi. Jakarta: Kencana Prenada Group.

Mulyasa, E., 2003. Kurikulum Berbasis Kompetensi: Konsep, Karakteristik, dan Implementasi. Bandung: PT Remaja Rosdakarya

Nawawi, H. 1997. Manajemen Sumber Daya Manusia. Yogyakarta. Gajah Mada Universitas Press.

Shakoor, A., Ghumman, M.S., Mahmood, T. 2013. Effect of In Service Training on the Working Capacity and Performance of Science Teachers at Secondary Level. Jurnal of Educational and Sosial Research MCSER Publishing, Rome-Italy, 3(3), pp. 337-342.

Sulistyawardani, Naniek dkk. 2012. Asesmen Pembelajaran Bahan Belajar Mandiri SD. Salatiga: Widya Sari Press Salatiga.

Syah, Muhibbin. 2000. Psikologi Pendidikan dengan Pendekatan Baru. Bandung: PT Remaja Rosdakarya.

2005. Undang-Undang RI No. 14 Th. 2005 Tentang Guru dan Dosen. Jakarta: Depdiknas.

2007. Peraturan Menteri Pendidikan Nasional No. 16 Tahun 2007 tentang Standar Kompetensi Guru. Jakarta:Depdiknas. 